\title{
PENGARUH RASIO PUREE KROKOT (PORTULACA OLERACEA L.) DAN SARI KEDELAI TERHADAP SIFAT ORGANOLEPTIK MELLORINE
}

\author{
Wiwik Wahyuni ${ }^{1}$, Laili Hidayati ${ }^{2}$ \\ 1,2Program Studi Tata Boga, Fakultas Teknik \\ ${ }^{1,2}$ Universitas Negeri Malang \\ wiwikwahyuni.ft@um.ac.id
}

\begin{abstract}
ABSTRAK
Tujuan penelitian ini adalah menganalisis pengaruh rasio puree krokot dan sari kedelai terhadap sifat organoleptik yang meliputi mutu hedonik (flavor dan tekstur) dan hedonik (warna, flavor dan tekstur) mellorine. Penelitian ini merupakan penelitian eksperimen dengan rancangan penelitian menggunakan Rancangan Acak Lengkap (RAL) dua kali pengulangan dengan tiga perlakuan yaitu rasio puree krokot dan sari kedelai 20\%:80\%, 40\%:60\%, dan 60\%:40\%. Analisis data menggunakan ANOVA dengan uji lanjut DMRT. Hasil penelitian uji mutu hedonik (flavor dan tekstur) dan uji hedonik (warna, flavor, dan tekstur) mellorine rasio puree krokot dan sari kedelai 20\%:80\%, 40\%:60\%, dan 60\%:40\% terdapat pengaruh yang signifikan pada taraf 5\%. Rerata skor uji mutu hedonik dan uji hedonik tertinggi diperoleh dari mellorine rasio puree krokot dan sari kedelai 20\%:80\%
\end{abstract}

Kata Kunci: krokot, puree krokot, mellorine

\section{PENDAHULUAN}

Es krim merupakan salah satu jenis makanan yang sangat disukai oleh konsumen dari anak-anak hingga dewasa. Menurut [9], es krim adalah jenis makanan semi padat yang dibuat dengan cara pembekuan tepung es krim atau dari campuran susu, lemak hewani maupun nabati, gula, dengan atau tanpa bahan makanan lain dan bahan makanan tambahan lain yang diijinkan. Es krim menurut [2] merupakan salah satu makanan bernilai gizi tinggi.

Es krim adalah salah satu jenis frozen dessert yang popular dikalangan masyarakat. Selain es krim, frozen dessert lainnya yang tidak kalah popular yaitu velva, sorbet, gelato, dan mellorine. Mellorine adalah jenis makanan pencuci mulut berbentuk beku seperti es krim yang sebagian atau seluruh lemak susunya diganti dengan lemak nabati dengan kadar lemak rendah. Mellorine dapat menjadi solusi bagi konsumen yang memperhatikan diet rendah lemak. Mellorine mengandung tidak kurang dari 6\% lemak, dengan formula, proses pembuatan dan sifat-sifat yang sama seperti es krim [3]

Salah satu lemak nabati yang dapat digunakan pada pembuatan mellorine yaitu sari kedelai. Sari kedelai merupakan cairan hasil ekstraksi biji kedelai dengan air panas dan dapat dijadikan sebagai alternatif pengganti lemak susu yang berasal dari susu sapi karena mempunyai kandungan gizi yang hampir sama, yaitu dalam $100 \mathrm{~g}$ kedelai mengandung 41 kalori, 2,5 g lemak, dan 3,5 g protein, sedangkan kandungan kalori, lemak, dan protein susu sapi berturut-turut sebesar 61 kalori, 3,5 g dan 3,2 g [5].

Bahan penstabilperlu ditambahkan dalam pembuatan mellorine yang berfungsi untuk mencegah terjadinya kristalisasi es selama penyimpanan. Jenis dan jumlah bahan yang digunakan sebagai penstabil berpengaruh terhadap nilai overrun, kecepatan meleleh dan warna pada es krim [6]. Bahan alami yang dapat berfungsi sebagai bahan penstabil suatu makanan yaitu pektin, pati, dan ekstrak rumput laut[13]. Pektin secara umum terdapat di dalam 
dinding sel tanaman [12]. Salah satu tanaman yang mengandung pektin yaitu krokot.

Krokot (Portulaca oleracea L.) merupakan tanaman yang tumbuh di daerah terbuka dan banyak dijumpai di sela-sela tanaman palawija [7]. Berdasarkan latar belakang di atas, maka akan dilakukan penelitian tentang pengaruh rasio puree krokot (Portulaca oleracea L.) dan sari kedelai terhadap sifat organoleptik mellorine.

Tujuan penelitian ini adalah menganalisis pengaruh rasio puree krokot dan sari kedelai 20\%:80\%, 40\%:60\%, dan 60\%:40\% terhadap sifat organoleptik yang meliputi mutu hedonik (flavor dan tekstur) dan hedonik (warna, flavor dan tekstur) mellorine

\section{METODE}

Penelitian ini merupakan penelitian eksperimen dengan rancangan penelitian menggunakan Rancangan Acak Lengkap (RAL) dua kali pengulangan dengan tiga perlakuan yaitu rasio puree krokot dan sari kedelai 20\%:80\%, 40\%:60\%, dan 60\%:40\%. Rancangan pada penelitian ini menggunakan rancangan acak lengkap (RAL) dapat dilihat pada Tabel 1.

Tabel 1 Rancangan Penelitian

\begin{tabular}{llll}
\hline \multirow{2}{*}{ Pengulangan } & \multicolumn{3}{l}{ Perlakuan } \\
\cline { 2 - 4 } & 457 & 236 & 891 \\
\hline P1 & $457-\mathrm{P} 1$ & $236-\mathrm{P} 1$ & $891-\mathrm{P} 1$ \\
$\mathrm{P} 2$ & $457-\mathrm{P} 2$ & $236-\mathrm{P} 2$ & $891-\mathrm{P} 2$ \\
\hline
\end{tabular}

Keterangan:

457 : Mellorine dengan rasio puree krokot dan sari kedelai 20\%:40\%

236 : Mellorine dengan rasio puree krokot dan sari kedelai 40\%:60\%

891 : Mellorine dengan rasio puree krokot dan sari kedelai 60\%:40\%

P1 : Pengulangan 1

P2 : Pengulangan 2

Bahan yang digunakan dalam pembuatan mellorine adalah sari kedelai, puree krokot, susu skim, gula pasir, dan kuning telur .Alat yang digunakan dalam membuat mellorine substitusi puree krokot adalah timbangan digital, gelas ukur, pisau, cutting board, baskom, spatula, sendok, kompor, pan, ladle, termometer suhu, blender, mixer, votator,freezer. Kegiatan penelitian ini meliputi pembuatan puree krokot, pembuatan sari kedelai dan pembuatan mellorine. Diagram alir pembuatan mellorine dapat dilihat pada Gambar 1.

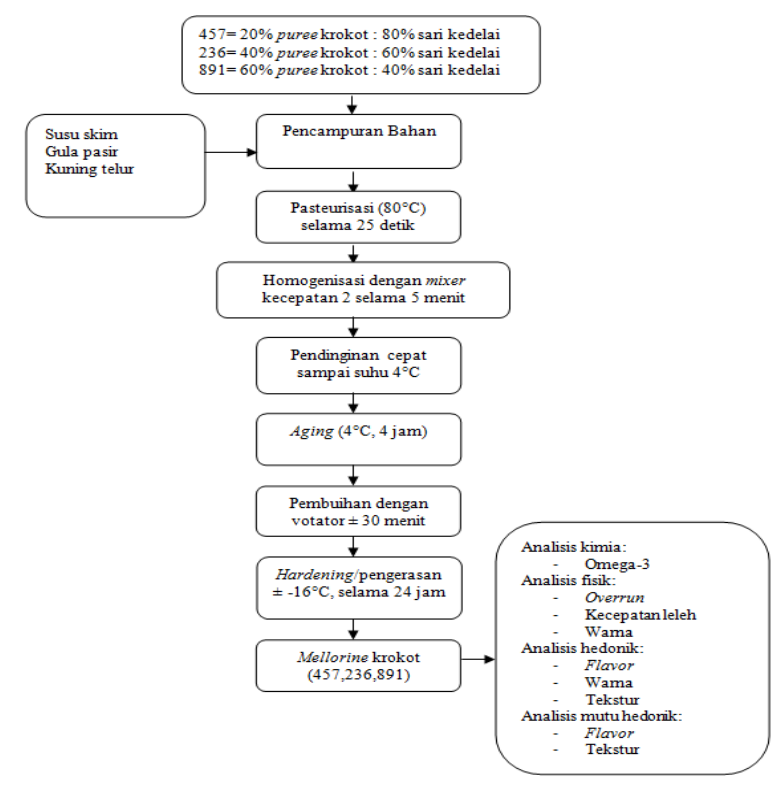

Gambar 1 Diagram Alir Pembuatan Mellorine Rasio PureeKrokot dan Sari Kedelai yang Berbeda

Selanjutnya dilakukan uji organoleptik (uji hedonik dan uji mutu hedonik). Instrumen yang digunakan berupa angket dilakukan dengan memberikan tanda checklist $(\sqrt{ })$ pada jawaban yang sesuai menurut panelis.

Data yang diperoleh dianalisis secara statistik menggunakan uji ANOVA (Analysis of Variance). Apabila data yang telah dianalisis menggunakan uji ANOVA (Analysis of Variance) terdapat perbedaan, maka dilanjut dengan DMRT (Duncan Multiple Range Test) untuk mengetahui perbedaan diantara masingmasing perlakuan. 


\section{HASIL DAN PEMBAHASAN}

\section{Uji Mutu Hedonik}

Penilaian uji mutu hedonik flavormellorine dengan rasio puree krokot dan sari kedelai yang berbeda mempunyai kriteria dari tidak langu (5), kurang langu (4), agak langu (3), cukup langu (2), langu (1). Penilaian uji mutu hedonik tekstur mellorine dengan rasio puree krokot dan sari kedelai yang berbeda mempunyai kriteria dari lembut (5), cukup lembut (4), agak lembut (3), kurang lembut (2), tidak lembut (1). Berdasarkan hasil penelitian,gambar rerata hasil uji mutu hedonik flavor dan tekstur mellorine dengan rasio puree krokot dan sari kedelai yang berbeda dapat dilihat pada Gambar 2.

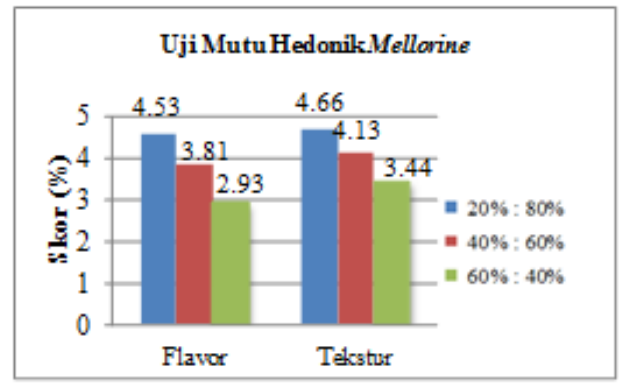

Gambar 2. Rerata Hasil Uji Mutu Mellorine

Hasil analisis mutu hedonik flavor dan tekstur mellorinedengan rasio puree krokot dan sari kedelai 20\%:80\%, 40\%:60\% dan 60\%:40\% menunjukkan terdapat pengaruh yang signifikan.Flavor yang dihasilkan dari mellorinedengan rasio puree krokot dan sari kedelai yang berbeda antara cukup langu hingga kurang langu dengan skor 2,93-4,53. Krokot merupakan sayuran hijau yang memiliki flavor langu. Hal ini disebabkan karena sayuran hijau mengandung enzim lipoksidase yang bila proses pemasakannya tidak sempurna dapat menimbulkan aroma langu (Andarwulan, 2014).Puree krokot memberikan pengaruh yang besar terhadap flavor mellorine. Hal ini dibuktikan dengan semakin banyak puree krokot yang digunakan maka flavor langu pada mellorine semakin kuat.
Tekstur yang dihasilkan dari mellorine dengan rasio puree krokot dan sari kedelai yang berbeda antara agak lembut sampai lembut dengan skor 3,44-4,66.Komposisi dalam pembuatan mellorine adalah sari kedelai, puree krokot, kuning telur, susu skim dan gula pasir. Puree krokot memiliki tekstur yang kurang lembut, sehingga semakin banyak puree krokot yang digunakan maka tingkat kelembutan mellorine semakin berkurang. Tekstur es krim bergantung dari ukuran, bentuk dan ukuran partikel padatan penyusun es krim. Tekstur yang ideal bagi es krim adalah tekstur yang sangat halus dan ukuran partikel padatan yang sangat kecil sehingga tidak terdeteksi dalam mulut (Widiantoko, 2011).

\subsection{Uji Hedonik}

Penilaian uji hedonik warna, flavor dan tekstur mellorine dengan rasio puree krokot dan sari kedelai yang berbeda mempunyai kriteria dari suka (5), agak suka (4), netral (3), agak tidak suka (2), tidak suka (1). Berdasarkan hasil penelitian,gambar rerata hasil uji hedonic warna, flavor dan tekstur mellorine dengan rasio puree krokot dan sari kedelai yang berbeda dapat dilihat pada Gambar 3.

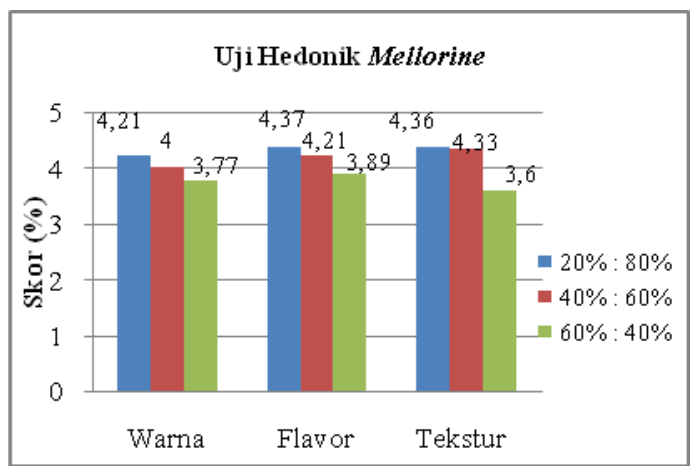

Gambar 3. Rerata Hasil Sifat Fisik Warna Mellorine

Hasil analisis hedonik warna,flavor dan tekstur mellorine dengan rasio puree krokot dan sari kedelai 20\%:80\%, 40\%:60\% dan 60\%:40\% menunjukkan terdapat pengaruh yang signifikan.Uji hedonik warna yang dihasilkan dari mellorine dengan rasio puree krokot dan sari kedelai yang berbedanetral 
hingga agak suka $(3,77-4,21)$. Tingkat kesukaan panelis terhadap warna mellorine semakin menurun karena warna mellorine

semakin gelap dan kurang menarik. Suatu bahan pangan yang dinilai bergizi, enak dan teksturnya sangat baik, tetapi apabila memiliki warna yang kurang menarik untuk dipandang akan memberikan kesan yang menyimpang dari warna yang seharusnya [12].

Uji hedonik flavor yang dihasilkan dari mellorinedengan rasio puree krokot dan sari kedelai yang berbedaantara netral hingga agak suka $(3,89-4,37)$ karena semakin banyak puree krokot yang digunakan maka flavor langu pada mellorine semakin kuat. Terdapat perbedaan tingkat kesukaan flavor pada mellorinedengan rasio pureekrokot dan sari kedelai 20\%:80\%, 40\%:60\% dan 60\%:40\% karena setiap orang memiliki perbedaan selera rasa. Menurut [12], setiap orang memiliki batas konsentrasi terendah terhadap suatu rasa agar masih bisa dirasakan.

Uji hedonik tekstur yang dihasilkan dari mellorinedengan rasio puree krokot dan sari kedelai yang berbedaantara netral hingga agak suka $(3,6-4,36)$. Semakin banyak puree krokot yang digunakan menyebabkan tingkat kesukaan panelis terhadap tekstur mellorine semakin berkurang. Hal ini diduga karena puree krokot memiliki tekstur yang kurang lembut, sehingga semakin banyak puree krokot yang digunakan maka tingkat kelembutan mellorine semakin berkurang. Tekstur yang lembut pada es krim sangat dipengaruhi oleh komposisi campuran, pengolahan, dan penyimpanan [10].

\section{SIMPULAN DAN SARAN}

Berdasarkan hasil penelitian dan pembahasan "Pengaruh Rasio Puree Krokot (Portulaca oleracea L.) dan Sari Kedelai Terhadap Sifat Organoleptik Mellorine.” maka dapat disimpulkan bahwa sifat organoleptik yang meliputi mutu hedonik (flavor dan tekstur) dan hedonik (warna, flavor dan tekstur) mellorine dengan rasio puree krokot dan sari kedelai 20\%:80\%, 40\%:60\% dan 60\%:40\% menunjukkan terdapat

pengaruh yang signifikan. Rerata skor uji mutu hedonik dan uji hedonik tertinggi diperoleh dari mellorine rasio puree krokot dan sari kedelai 20\%:80\% .

\section{REFERENSI}

[1] Andarwulan, Nuri. 2014. Agar Sayur Tidak Langu.

(Online), (http://www.femina.co.id/kuliner/info.kuli ner/agar.sayur.tidak.langu/004/002/3), diakses 5 Oktober 2015.

[2] Astawan, M. 2007. Ada Penjinak Virus di Dalam Es Krim. Bogor:IPB.

[3] Hubeis Musa, Nuri A, Winda Y. 1996. Kajian Teknologi dan Financial Produksi Es Krim (mellorine) Skala Kecil. Buletin Teknologi dan Industri Pangan. 7 (1):1-7.

[4] Irawan, Daisy et al. 2003. The Potency of Krokot (Portulaca oleracea) as Functional Food Ingredients. Bogor: Institut Pertanian Bogor.

[5] Koswara, S. 2006. Susu Kedelai tak Kalah dengan Susu Sapi. Jurusan Teknologi Pangan dan Gizi Fakultas Teknologi Pertanian IPB. Bogor.

[6] Priastami Syafriliana, Cendrawasih. 2011. Karagenan sebagai Bahan Penstabil pada Proses Pembuatan Mellorine. Bogor: Intitut Pertanian Bogor.

[7] Rahardjo, M. 2007. Krokot (Portulaca oleracea) Gulma Berkhasiat Obat Mengandung Omega 3. Warta Penelitian dan Pengembangan Tanaman Industri,(Online),13(1):1-4, (http://perkebunan.litbang.pertanian.go.id/ upload.files/File/publikasi/warta/warta Vo 1_13_No.1_2007.pdf), diakses 15 Juni 2015.

[8] Simopoulos, AP. 2004. Omega-3 Fatty Acids and Antioxidants in Edible Wild Plants. American Journal Clinical Nutrition. 37: 263-277. 
[9] SNI. 1995. Standar Nasional Indonesia (SNI) 01-0317-1995. Jakarta: Badan Standarisasi Nasional.

[10] Syahbania, N. 2012. Studi Pemanfatan Talas (Colocasia esculenta) Sebagai Bahan Pengisi dalam Pembuatan Es Krim. Fakultas Pertanian Universitas: Hasannudin Sulawesi Selatan.

[11] Widiantoko, R.K. 2011. Es Krim. (Online).

(http://lordbroken.wordpress.com/2011/0 4/10), diakses 5 April 2015.
[12] Winarno, F.G. 2004. Kimia Pangan dan Gizi. Jakarta: Gramedia Pustaka Utama.

[13] Yoantika, E. F. 2014. Pengaruh Stabilizer Pati Ubi Jalar Terhadap Karakteristik Fisik, Kimia, dan Organoleptik Es Krim STMJ. Skripsi tidak diterbitkan. Malang: Universitas Negeri Malang. 